\title{
The Effectiveness Of Psycoeducation Of Self-Concept In Children In Conflict With The Law At Children's Social Home X
}

\author{
Deena Pratiwi ${ }^{\mathrm{a}}$, Nilam Widyarini ${ }^{\mathrm{b}}$ \\ Gunadarma University, Indonesia (pratiwideena@gmail.com) \\ Gunadarma University, Indonesia (nilam.wid@gmail.com)
}

\begin{abstract}
A negative self-concept is a condition in which a person tends to view themselves badly. In general, children in conflict with the law tend to have a negative self-concept. Psychoeducation is one of the effective intervention methods to improve self-concept, through cognitive readiness by providing new understanding and information. The purpose of this study was to improve self-concept in children in conflict with the law by providing psychoeducational interventions. The subjects of this study were children in conflict with the law in Children's Social Home X, with total of 17 boys. The research method used is an experiment with the type of design in the form of a one group pretestposttest design. Hypothesis testing was carried out on the pre and post tests of the Self Concept Questionnaire using Wilcoxon. The psychoeducational intervention was given in the form of material presentation, group discussions, games, and activities that were carried out in three sessions with a duration of one hundred minutes in each. The results showed an increase in self-concept after being given psychoeducation on subject.
\end{abstract}

(C) 2021 Published by IJRP.ORG. Selection and/or peer-review under responsibility of International Journal of Research Publications (IJRP.ORG)

Keywords: psychoeducation; self-concept; children in conflict with the law

\section{Preliminary}

The number of children in conflict with the law is increasing every year. Throughout 2011-2017 there were a total of 9,266 cases involving them (Setyawan, 2017). The Indonesian Child Protection Commission also noted that children in conflict with the law cases were ranked as the highest complaint until May 2018. Of the 1885 complaints received, 504 of them (27\% of the total cases) were children in conflict with the law cases. In this case, a child was the perpetrator. The number is no less high. In 2018, there were 116 cases of children as perpetrators of sexual violence (Primastika, 2018).

The increase in the number of children in conflict with the law cases has the consequence of increasing the number of children in Children's Social Home X as partners of law enforcers. Social Home X is one of the social rehabilitation institutions that becomes a reference for children in conflict with the law care during the legal process. In general, the condition of children in conflict with the law comes from low economic and educational backgrounds. As a result, the motivation to fulfill economic needs is the trigger for the emergence of criminal cases that they commit. In addition, the lack of family attention causes a lack of supervision of children behavior. This is also supported by the condition of the children who are on average in their teens where they tend to look for self-identity in their peers.

These children also tend to feel depressed that arises from anxiety over their lack of understanding of themselves regarding future decision making after they finish serving their prison term. According to Brickman (in Prakoso, 2008) anxiety of the future is the tendency of individuals who are not sure that they will experience positive things compared to negative things in the future and believe that the future will be worse than the present. One of the factors that make these children unsure of themselves is their negative self-concept. 
Compared to individuals with negative self-views, those with positive self-views tend to be happier (Swann, 1990), more well-adjusted (Dumont \& Provost, 2001), and more socially acceptable (Jackson \& Bracken, 1998). ), have a better sense of belonging (DeNeve \& Cooper, 1998; McCullough, Huebner, \& Laughlin, 2000), express greater life satisfaction (Diener \& Diener, 1995; Terry \& Huebner, 1995), come from an intact family ( Sweeney \& Bracken, 2000), and have a low tendency to run away from home (Swaim \& Bracken, 1997).

Based on the results of the initial assessment carried out on these children in Children's Social Home X, it was found that they believe their current status will always be part of their identity which will cause negative stigma in society. This causes them to feel that their future has been destroyed and cannot be fixed. In addition, these children are also pessimistic about being able to achieve their goals. So it can be concluded that almost all children in Children's Social Home X have a negative self-concept.

Children in conflict with the law who have a positive self-concept will be better prepared to face life in society after the detention period is over, while those who have a negative self-concept tend to be unprepared so that it can result in a tendency to depression and be at risk for repeating crimes that have been committed.

The process of modifying the self-concept can be done through an intervention. The form of intervention that will be used to improve self-concept in this study is psychoeducation. Psychoeducation is an intervention that can be carried out on individuals, families, or groups that focus on educating participants about significant challenges in life, helping participants develop sources of support and social support in dealing with challenges and developing coping skills (Walsh, 2010). Research conducted by Palomino (2017) proves that the provision of mindfulness-based psychoeducational interventions is effective in improving self-concept in adolescents.

According to Leff, Kuipers, Berkowitz, Eberlein-Vries, and Sturgeon (1992) psychoeducation has several approaches, which informative, supportive, ability training, and comprehensive. Psychoeducation in this study uses a comprehensive approach because it contains elements of informative, supportive, and ability training. Subjects are given knowledge about self-concept through the presentation method. Furthermore, group discussions, games, and activities were carried out.

Based on the explanation that has been presented, the hypothesis that can be developed in this study is the provision of effective psychoeducational interventions in improving self-concept in the subject.

\section{Research Methods}

This study uses an experimental method with the type of design in the form of a one group pretest-posttest design. In this design, measurements were taken before the intervention was given to the research subjects. Then, when the intervention has been fully implemented or is assumed to have had an effect on the subject, measurements are made again to ascertain the impact provided by the intervention (Kumar, 2011).

The independent variable in this study was psychoeducation with the presentation method. The word 'psycho' refers to the various psychological ideas and theories that form the basis of the approaches, programs, and practices of various psychoeducational programs. While the word 'education' refers to the teaching and learning paradigm that largely shapes the content and practice of psychoeducational programs (Wood, Brendtro, Fecser, \& Nichols, 1999). The psychoeducation provided contains information about self-concept in general and examples of its aspects.

The dependent variable in this study is self-concept. Self-concept is an accumulation of an individual's perception of himself that is considered the center of personal identity and changes over time (Matsumoto, 2009). Self-concept has aspects (1) self image, which is how individuals see themselves, (2) self-esteem, which refers to the extent to which individuals like, accept, or approve of themselves, or how much individuals value themselves, and (3) ideal self, which is a concept that individuals want for the future (Rogers, in Feist \& Feist, 2009).

The instrument used to measure self-concept is the Self Concept Questionnaire from Robson (1989). An example of an item on the scale is "There are many things in me that I would like to change if I could". The answer choices for this scale range from 1-5, ranging from Strongly Disagree to Strongly Agree. This scale has 15 items with a reliability of 0.89 .

Subjects who received the intervention were children in conflict with the law who were in Social Home X, under the age of 17 , and entrusted by law enforcement parties in order to wait for a summons from the court. The number of subjects as many as 17 and all male.

Researchers provide psychoeducation with a presentation method to the subject. The psychoeducation was divided into four sessions. The first session contained general self-concept material, the application of self-image aspects through the game 
method, as well as daily journal assignments aimed at self-evaluation and making the subject focus more on positive things around them. The second session consisted of checking journal assignments and applying self-esteem aspects through games, watching movies, and group discussions. The third session consisted of checking journal assignments, applying the ideal aspect of self through group discussion methods, watching movies, and role playing, as well as giving letter assignments to friends aimed at expressing positive things in others. The fourth session is a closing session which contains checking journal assignments and evaluating the results, reviewing sessions 1-3, and distributing letters to friends.

The data analysis technique used in this study was a non-parametric test with Wilcoxon analysis through SPSS to see changes before and after the intervention was given to the experimental group. Conformity appears when the empirical model obtained has a good goodness of fit with probability $>0.05$.

\section{Discussion}

The subjects in this study amounted to 17 people, all of whom were male. Subjects age ranges from 12 to 17 years old with a total of 5 people at the age of 12-14 years and 12 people at the age of 15-17 years. A total of nine subjects had their last education at the elementary school level, three subjects at high school, and five subjects at high school or the equivalent. The subject's socio-economic conditions were 16 people in the low category and only one person in the middle category. The results can be seen in Table 1 .

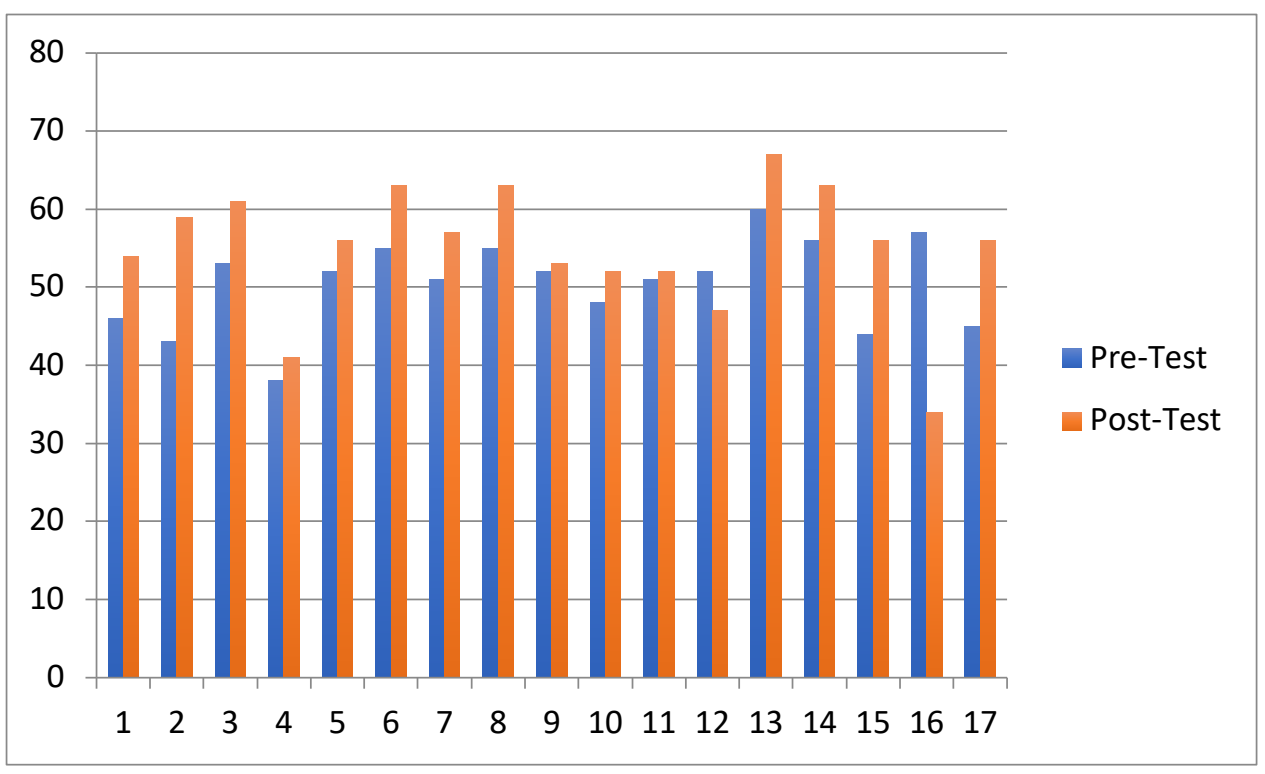

Fig.1 The result of pre-test and post-test of the self-concept questionnaire

Based on Figure 1, it can be seen that 15 out of 17 subjects showed an increase in self-concept after being given psychoeducational intervention. This is seen based on the post-test score which is higher than the pre-test score. However, two subjects experienced a decrease.

\begin{tabular}{|c|c|c|c|c|}
\hline \multirow{2}{*}{$\mathrm{N}$} & \multicolumn{2}{|c|}{ Mean } & \multirow{2}{*}{ Z } & \multirow{2}{*}{$\mathrm{P}$} \\
\hline & Pre-Test & Post-Test & & \\
\hline 17 & 50.4706 & 54.9412 & -2.537 & .011 \\
\hline
\end{tabular}

Fig. 2 Average pre-test and post-test results 
Figure 2 shows the average score of the subject's self-concept score has increased from 50.47 to 54.94 . In addition, the significance value showed $0.011(\mathrm{p}<0.05)$. Thus, it can be concluded that the intervention in the form of psychoeducation is significant and effective in improving the self-concept of the subject.

The results of this study are in line with the results of research conducted by Wells, Miller, Tobacyk, and Clanton (2002) which showed a significant increase in self-esteem and self-concept of adolescents after being given psychoeducation. The research conducted by Palomino (2017) also proves that the provision of mindfulness-based psychoeducational interventions is effective in improving self-concept in adolescents.

According to Bracken (2009), psychoeducation can improve self-concept in adolescents if the the researcher can help adolescents perceive themselves as better individuals than before, more competent, and self-accepting. This is manifested in a number of activities, such as daily journal assignments, self-reflection drawing and self-help writing, and role play advertising self-kindness. At first, most of the subjects found it difficult to find the good in themselves. So, the researcher need to provide motivation and share a little positive perception from the researcher on the subject until the subject believes that he does have that goodness, after that the subject tends to find it easier to find other goodness.

Furthermore, Cooley (1992) explains that self-concept can be improved if the researcher can make the environment around the subject more supportive, accepting, reassuring, and can provide reinforcement. Psychoeducation can show good results when the intervention provider can show support, optimism, and unconditional acceptance of the subject. This is manifested in providing activities to write letters to friends, group discussions, and reviewing daily journal assignments. According to McBride (2010), psychoeducation can help a person to know and understand himself better. Thus, the more knowledge a person has about himself, the better the person will live with the conditions he has.

However, there were two subjects who experienced a decrease in the post-test score of self-concept. So the researchers conducted interviews on the two subjects. The first subject said that he was feeling unmotivated in doing everything at Social Home X. This happened because the subject was feeling very depressed because no family had visited him from the first day the subject was at Social Home X. The subject thought that his family did not love and abandoned him so that he feels very sad and hopeless. This is in accordance with the opinion of Manning (2007) which says that providing support from significant others (parents and family) can affect adolescent self-concept. Research conducted by Ybrandt (2008) also says that a negative self-concept in adolescents is closely related to depression and anxiety.

Meanwhile, another subject said that he had not been able to adapt to the environment of Social Home X because he had only entered the day before the research was conducted. In addition, the subject also felt that he did not have friends and was very awkward to establish communication because other subjects tended to be in groups. This is in accordance with the opinion of Asher and Coie (1990) who say that rejection from peers can damage a sense of belonging, inhibit social relations, and in the long run can affect a teenager's self-concept. Meanwhile, Altermatt and Pomerantz (2003) say that peers who are in the same environment play an important role in building adolescent self-concept.

\section{Conclusion}

Interventions with psychoeducational methods are significant and effective in improving self-concept on subjects who are children facing the law in Social Home X. This is because psychoeducation is effective in changing perceptions and increasing understanding and self-awareness of the potential possessed within the subject. The results of this study confirm the results of previous research. In addition, there is a decrease in self-concept in two subjects, indicating that external factors from the subject still need to be considered and can be involved in the next self-concept study with the context of the problem or different participants.

There are several suggestions that can be made regarding the results of this study. First, consider various dimensions of self-concept so that it can be seen which aspects of self-concept are increasing. Second, adding gender so that the comparison between the two can be known. Third, adding a control group so that it can be seen the increasing effectiveness of psychoeducation. 


\section{References}

Altermatt, E., \& Pomerantz, E. (2003). The development of competence-related and motivational beliefs: An investigation of similarity and influence among friends. Journal of Educational Psychology, 95, 11-23.

Asher, S., \& Coie, J. (1990). Peer rejection in childhood. Cambridge, UK: Cambridge University Press.

Callhoun, F., \& Acocella, J. R. (1990). Psikologi: Penyesuaian hubungan kemanusiaan. Edisi ketiga. Semarang: IKIP Semarang Press.

Cooley, C. H. (1992). Human nature and the social order. New York: Scribner's.

DeNeve, K. M., \& Cooper, H. (1998). The happy personality: A meta-analysis of 137 personality traits and subjective well-being. Psychological Bulletin, $124,197-229$.

Diener, E., \& Diener, M. (1995). Cross-cultural correlates of life satisfaction and self-esteem. Journal of Personality and Social Psychology, 69, $120-129$.

Dumont, M., \& Provost, M. A. (2001). Resilience in adolescents: Protective role of social support, coping strategies, self-esteem, and social activities on experience of stress and depression. Journal of Youth and Adolescence, 28, 343-363.

Feist, J., \& Feist, G. J. (2009). Theories of personality. New York: Mc Graw Hill.

Jackson, L. D., \& Bracken, B. A. (1998). Relationship between students social-status and global and domain-specific self-concepts. Journal of School Psychology, 36, 233-245.

Kumar, R. (2011). Research methodology: A step-by-step guide for beginners ( ${ }^{\text {rd }}$ edition). Los Angeles: SAGE Publications Ltd.

Manning, M. (2007). Self-concept and self-esteem in adolescents. Student Services, 11-15

Matsumoto, D. (2009). The cambridge dictionary of psychology. Cambridge: Cambridge University Press.

McBride, M. (2010). The effects of brief psychoeducation on adolescents depressive symptoms and perceptions of parenting (doctoral dissertations). Missoula, MT: Doctor of Philosophy in Clinical Psychology University of Montana. (diakses dalam https://scholarworks.umt.edu/etd/998/?utm_source= scholarworks.umt.edu\%2Fetd\%2F998\&utm_medium=PDF\&utm_campaign=PDFCoverPages)

McCullough, G., Huebner, E. S., \& Laughlin, J. E. (2000). Life events, self-concept, and adolescents' positive subjective well-being. Psychology in the Schools, 37, 281-290.

Palomino, M. (2017). An analysis of self-concept in students with compensatory education needs for developing a mindfulness-based psychoeducational program. SAGE Open, 1-11

Prakoso, F. (2008). Hubungan antara konsep diri dengan kecemasan menghadapi masa depan pada narapidana di lembaga pemasyarakatan IIb Klaten. (Skripsi tidak diterbitkan). Surakarta: Fakultas Psikologi Universitas Muhammadiyah.

Primastika, W. (2018). Penyebab kriminalitas anak: Kurang kasih sayang dan pengakuan sosial. (diakses dalam https://tirto.id/penyebab-kriminalitas-anakkurang-kasih-sayang-amp-pengakuan-sosial-cP3F)

Robson, (1989). Development of a new self-report questionnaire to measure self-esteem. Psychological Medicine, 19, 513-518.

Setyawan, D. (2017). KPAI: Kurun waktu 6 tahun, abh sudah mencapai 9.266 kasus. (diakses dalam http://www.kpai.go.id/berita/kpai-kurun-waktu-6-tahunabh-sudah-mencapai-9-266-kasus)

Swann, W. B. (1990). To be adored or to be known: The interplay of self-enhancement and self-verification. In R. M. Sorrentino \& E. T. Higgins (Eds.), Motivation and cognition. (Vol. 2, pp. 408-448). New York: Guilford.

Swaim, K. F., \& Bracken, B. A. (1997). Global and domain-specific self-concepts of a matched sample of adolescent runaways and nonrunaways. Journal of Clinical Child Psychology, 26, 397-403.

Sweeney, R. B., \& Bracken, B. A. (2000). Influence of family structure on children's self-concept development. Canadian Journal of School Psychology, 16, $39-52$.

Terry, T., \& Huebner, E. S. (1995). The relationship between self-concept and life satisfaction in children. Social Indicators Research, 35, 39-52.

Walsh, J. (2010). Psychoeducation in mental health: Practice, research, and policy. Chicago: Lyceum Books, Inc.

Wells, D., Miller, M., Tobacyk, J., \& Clanton, R. (2002). Using a psychoeducational approach to increase the self-esteem and seld-concept of adolescents at high risk for dropping out. Adolescence, 37(146), 431-4.

Wood, M. M., Brendtro, L. K., Fecser, F. A., \& Nichols, P. (1999). Psychoeducation: An idea whose time has come. Reston, Virginia: Council for Children with Behavioral Disorders.

Ybrandt, H. (2008). The relation between self-concept and social functioning in adolescence. J. Adolesc, 31, 1-16. 